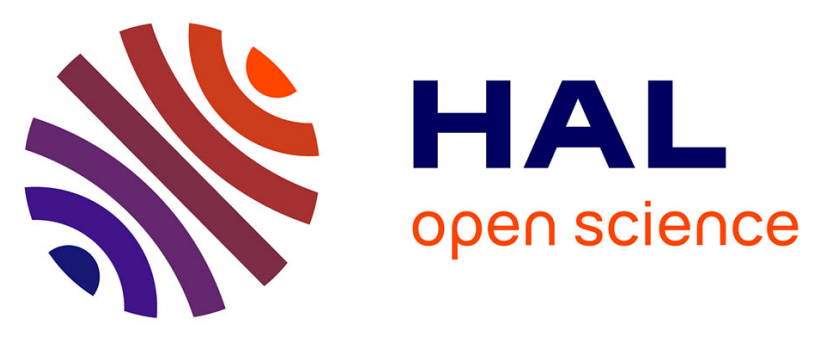

\title{
Use of geochemical signatures, including rare earth elements, in mosses and lichens to assess spatial integration and the influence of forest environment
}

L. Gandois, Yannick Agnan, Sébastien Leblond, Nathalie Séjalon-Delmas, Gaël Le Roux, Anne Probst

\section{To cite this version:}

L. Gandois, Yannick Agnan, Sébastien Leblond, Nathalie Séjalon-Delmas, Gaël Le Roux, et al.. Use of geochemical signatures, including rare earth elements, in mosses and lichens to assess spatial integration and the influence of forest environment. Atmospheric environment, 2014, 95, pp. 96-104. 10.1016/j.atmosenv.2014.06.029 . hal-01252240

\author{
HAL Id: hal-01252240 \\ https://hal.science/hal-01252240
}

Submitted on 7 Jan 2016

HAL is a multi-disciplinary open access archive for the deposit and dissemination of scientific research documents, whether they are published or not. The documents may come from teaching and research institutions in France or abroad, or from public or private research centers.
L'archive ouverte pluridisciplinaire HAL, est destinée au dépôt et à la diffusion de documents scientifiques de niveau recherche, publiés ou non, émanant des établissements d'enseignement et de recherche français ou étrangers, des laboratoires publics ou privés. 


\section{OATAO \\ Open Archive Toulouse Archive Ouverte}

\section{Open Archive TOULOUSE Archive Ouverte (OATAO)}

OATAO is an open access repository that collects the work of Toulouse researchers and makes it freely available over the web where possible.

This is an author-deposited version published in : http://oatao.univ-toulouse.fr/ Eprints ID : 14624

To link to this article : DOI:10.1016/j.atmosenv.2014.06.029

URL : http://dx.doi.org/10.1016/j.atmosenv.2014.06.029

To cite this version : Gandois, L. and Agnan, Yannick and Leblond, Sébastien and Séjalon-Delmas, Nathalie and Le Roux, Gaël and Probst, Anne Use of geochemical signatures, including rare earth elements, in mosses and lichens to assess spatial integration and the influence of forest environment. (2014) Atmospheric Environment, vol. 95. pp. 96-104. ISSN 13522310

Any correspondance concerning this service should be sent to the repository administrator: staff-oatao@listes-diff.inp-toulouse.fr 


\title{
Use of geochemical signatures, including rare earth elements, in mosses and lichens to assess spatial integration and the influence of forest environment
}

\author{
L. Gandois ${ }^{\text {a, b, * , Y. Agnan }}{ }^{\text {a, b }}$, S. Leblond ${ }^{c}$, N. Séjalon-Delmas ${ }^{\text {a, b }}$, G. Le Roux ${ }^{\text {a, b }}$, \\ A. Probst ${ }^{\mathrm{a}, \mathrm{b}}$ \\ ${ }^{a}$ Université de Toulouse, INP, UPS, EcoLab (Laboratoire Ecologie Fonctionnelle et Environnement), ENSAT, Avenue de l'Agrobiopole, 31326 Castanet-Tolosan, \\ France \\ b CNRS, EcoLab, 31326 Castanet-Tolosan, France \\ ${ }^{\text {c } M u s e ́ u m ~ N a t i o n a l ~ d ' H i s t o i r e ~ N a t u r e l l e, ~} 57$ rue Cuvier, Case 39, 75005 Paris, France
}

\section{H I G H L I G H T S}

- Coupled analysis of TM signature and REE in forest ecosystem compartments.

- Regional integration of atmospheric deposition by biomonitors.

- Mosses reflect canopy influence on TM atmospheric deposition.

\section{A R T I C L E I N F O}

\section{Article history:}

Received 4 December 2013

Received in revised form

11 June 2014

Accepted 12 June 2014

Available online 13 June 2014

\section{Keywords:}

Mosses

Lichens

Trace metal

Rare earth element

Bulk deposition

Throughfall

\begin{abstract}
A B S T R A C T
In order to assess the influence of local environment and spatial integration of Trace Metals (TM) by biomonitors, $\mathrm{Al}, \mathrm{As}, \mathrm{Cd}, \mathrm{Cr}, \mathrm{Cs}, \mathrm{Cu}, \mathrm{Fe}, \mathrm{Mn}, \mathrm{Ni}, \mathrm{Pb}, \mathrm{Sb}, \mathrm{Sn}, \mathrm{V}$ and $\mathrm{Zn}$ and some rare earth element (REE) concentrations have been measured in lichens and mosses collected in three French forest sites located in three distinct mountainous areas, as well as in the local soil and bedrock, and in both bulk deposition (BD) and throughfall (TF). Similar enrichment factors (EF) were calculated using lichens and mosses and local bedrock for most elements, except for $\mathrm{Cs}, \mathrm{Mn}, \mathrm{Ni}, \mathrm{Pb}$, and $\mathrm{Cu}$ which were significantly (KW, $p<0.05)$ more enriched in mosses. Similar REE ratios were measured in soils, bedrock, lichens and mosses at each study sites, indicating a regional integration of atmospheric deposition by both biomonitors. Both TM signature and REE composition of mosses revealed that this biomonitor is highly influenced by throughfall composition, and reflect atmospheric deposition interaction with the forest canopy. This explained the higher enrichment measured in mosses for elements which concentration in deposition were influenced by the canopy, either due to leaching $(\mathrm{Mn})$, direct uptake $(\mathrm{Ni})$, or dry deposition dissolution $(\mathrm{Pb}, \mathrm{Cu}, \mathrm{Cs})$.
\end{abstract}

\section{Introduction}

Trace metals (TM: Al, As, Cd, Cr, Cs, Cu, Fe, Mn, Ni, Pb, Sb, Sn, V and $\mathrm{Zn}$ ) are highly dispersed in the atmosphere, mostly by human emissions (Nriagu and Pacyna, 1988; Steinnes et al., 1997; Rauch and Pacyna, 2009), with potential harmful effects on ecosystems (Ulrich and Pankrath, 1983; Nriagu, 1990; Adriano, 2001). In order

\footnotetext{
* Corresponding author. CNRS, EcoLab, 31326 Castanet-Tolosan, France.

E-mail addresses: laure.gandois@gmail.com, laure.gandois@ensat.fr (L. Gandois).
}

to survey extensively TM dispersion in the environment and their potential impact on ecosystems, large scale studies often use biomonitors (Boileau et al., 1982; Harmens et al., 2008; Steinnes, 1995). Lichens and mosses are ubiquitous in forest ecosystems, and have been widely used as monitors of TM atmospheric pollution mainly because they lack of any root system and have no or limited cuticles (Garty, 2001; Szczepaniak and Biziuk, 2003). Different TM accumulation capabilities have been reported for lichens and mosses (Nieboer et al., 1978; Beckett and Brown, 1984; Bargagli et al., 2002), and even between different lichen and moss species in relation to their various ecologies and morphologies. Lichens, 
which are slow growing association of fungi and algae, and mosses, can both grow on soils (terricolous) and tree barks (corticulous). These two groups of organisms have different life span: mosses live for a few years (During, 1979), when lichens have generally longer life span up to several decades (Manson and Hale, 1959; Armstrong and Bradwell, 2010). If regional correspondence could be established between estimation of $\mathrm{Cd}$ and $\mathrm{Pb}$ total deposition and their content in mosses (Harmens et al., 2012), an accurate estimation of TM atmospheric deposition cannot be established using TM content in mosses (Aboal et al., 2010). Trace metal accumulation in mosses and lichens is influenced by several processes, including uptake of elements from the soil and surrounding vegetation, and loss of elements (Boquete et al., 2011). In forested ecosystems, biomonitors receive atmospheric inputs that have been modified by the canopy. Concentrations of both major and trace elements are greatly influenced by the interaction with the forest cover, including assimilation or release of elements by the canopy and accumulation of dry deposition on leaves or needles (Heinrichs and Mayer, 1977; Godt et al., 1986; Probst et al., 1992; Gandois et al., 2010). These processes have to be taken into account when considering biomonitors collected in forested areas.

Rare earth elements (REE) are a group of trace chemical elements with similar physicochemical characteristics (Henderson, 1984). Different bedrocks show specific REE compositions Therefore, the pattern of the REE series is widely used to trace sources and processes in petrology (Weill and Drake, 1973; Chauvel and Jahn, 1984; Vidal et al., 1984) and Earth's surface sciences (Tricca et al., 1999; Aubert et al., 2001; Laveuf and Cornu, 2009). Their lithogenic origin and conservative behaviour make them pertinent tracers of dust dispersion. Rare earth element are directly analysed in aerosols (Ferrat et al., 2011; Gueguen et al., 2012; Yang et al., 2007) or in precipitations (Zhang and Liu, 2004; Spickova et al., 2010), or indirectly in peat bogs (Aubert et al., 2006; Shotyk et al., 2001 ) and lichens (Agnan et al., 2014) to investigate the origin of atmospheric deposition.

The objectives of this study are to assess the spatial integration and the influence of local forested environment on TM record by biomonitors in forest ecosystems. Two types of biomonitors have been selected for their contrasted ecology: terricolous mosses and corticolous lichens. In order to investigate elemental transfer in the forested ecosystems, tracers of elemental origin and mobility in ecosystems, including REE and TM signatures have been analysed in various compartments of the ecosystem: soil and bedrock, precipitation (open field and throughfall) and biomonitors. This study has been carried out in three contrasted forested sites, covering a wide range of environmental conditions, and located in three distinct mountainous areas in order to assess the spatial integration of biomonitors.

\section{Material and method}

\subsection{Study sites}

The study sites belong to the French RENECOFOR network (Réseau National de suivi à long terme des Ecosystèmes Forestiers, i.e. National Network for the long term Monitoring of Forest Ecosystems), managed by the ONF (Office National des Forêts, i.e. National Forest Board). This network is part of the ICP Forest network (International Co-operative Programme on Assessment and Monitoring of Air Pollution Effects on Forests, http://icp-forests.net). Three sites (EPC 08, EPC 63 and SP 11) were chosen because they are located, in three different mountainous areas (Ardennes, Massif Central, and Pyrenees) of France (Fig. 1, Table 1), and were previously investigated by Gandois et al. (2010) for trace metal deposition.

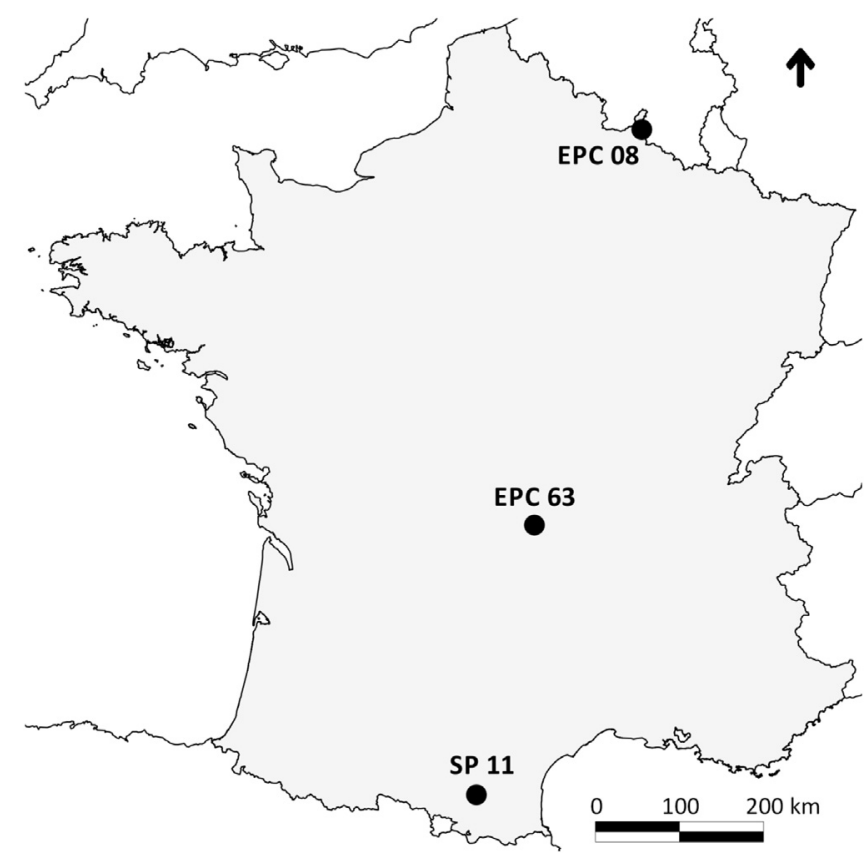

Fig. 1. Location of the three studied sites.

\subsection{Sample collection and preparation}

\subsubsection{Soils and bedrocks}

With regards to trace metal and REE, the soil and bedrock total composition was analysed within the ICP Forest network framework. Five soil samples were collected for each site $(0-10 \mathrm{~cm}$, $10-20 \mathrm{~cm}, 20-40 \mathrm{~cm}, 40-80 \mathrm{~cm}, 80-100 \mathrm{~cm}$ ) in 2007-2012 for the first four layers (using a hand auger) and in 1998-1999 for the deepest layer (in soil pit). The samples were sieved $(<2 \mathrm{~mm})$ and powdered before analyses.

\subsubsection{Atmospheric depositions}

In the studied sites, both BD and TF were sampled weekly for one year from September 2007 to October 2008 following a protocol described in Gandois et al. (2010). This publication focused on selected element ( $\mathrm{Al} \mathrm{Cu} \mathrm{Pb} \mathrm{Fe} \mathrm{Ni} \mathrm{Mn} \mathrm{Cd} \mathrm{Zn,} \mathrm{Sb).} \mathrm{We} \mathrm{included} \mathrm{here}$ the analysis of other elements (As, REE, see Table 2) that had been analysed in the samples (Gandois, 2009).

\subsubsection{Biomonitors}

2.2.3.1. Mosses. Mosses were collected in the vicinity of the RENECOFOR plots in 2007 and 2008, following an adaptation of the 2006 ICP Vegetation network protocol: (Harmens et al., 2008). Two terricolous species were sampled under the canopy and more than $3 \mathrm{~m}$ away from the tree trunks: Hypnum cupressiforme Hedw., (Hc) in ECP 08 and EPC 63, and Thuidium tamariscinum (Hedw.) B., S. \& G. (Tt) in EPC 63 and SP 11. Three replicates were sampled for each species. One replicate was made by pooling ten small plots of mosses collected on the soil. Mosses samples were brought back to the laboratory, dried at $40{ }^{\circ} \mathrm{C}$, and grinded in a Ti-mill. They were then digested $\left(\mathrm{H}_{2} \mathrm{O}_{2} / \mathrm{HNO}_{3}\right)$ in a clean room using a microwave oven at $220{ }^{\circ} \mathrm{C}$ and 20 bar pressure, following the ICP vegetation procedure (ICP Vegetation, 2005). The blanks showed no contamination during the digestion process: the measured concentrations were always below the detection limits. The repeatability of the method was checked by mineralisation and analytical determination of triplicates of samples. Coefficients of variation were less than $5 \%$. 
Table 1

Study sites description.

\begin{tabular}{|c|c|c|c|c|c|c|}
\hline Site & Location & Altitude (m a.s.l.) & Average annual precipitation ${ }^{a}(\mathrm{~mm})$ & Vegetation cover & Bedrock type & Soil type ${ }^{b}$ \\
\hline EPC 08 & Ardennes & & 1300 & Picea abies (L.) Karst. & Schist & Cambic podzol \\
\hline EPC 63 & Massif Central & & 990 & Picea abies (L.) Karst. & Basalt & Andosol \\
\hline SP 11 & Pyrenees & & 1100 & Albies alba Mill. & Carbonated marl & Stagnic luvisol \\
\hline
\end{tabular}

a Average for the period 1999-2005.

b WRB for soils (FAO).

2.2.3.2. Lichens. For lichen samples, sampling and mineralisation followed the protocol described by Agnan et al. (2013). Grown up lichens (several-year-old) were collected in 2011 on tree trunk using non-metallic material. Three corticolous lichen species were sampled among the most commonly found: Xanthroria parietina (L.) Th. Fr. (Xp) in the three sites, Parmelia sulcata Taylor (Ps) in EPC 63 and EPC 08, and Evernia prunastri (L.) Ach. (Ep) in EPC 08. Dried samples were powdered using nitrogen liquid and mineralised by an $\mathrm{HNO}_{3} / \mathrm{HF} / \mathrm{H}_{2} \mathrm{O}_{2}$ mixture in a cleanroom (EcoLab, Toulouse, France). The blank samples allowed checking no contamination during the procedure.

\subsection{Sample analysis}

Atmospheric deposition, moss and lichen samples were analysed for TM and REE with ICP-MS (7500 ce, Agilent Technologies, OMP-GET, Toulouse, France). The detection limit depended on the considered element: between 5 and $100 \mathrm{pg} \mathrm{g}^{-1}$. Indium $\left({ }^{115} \mathrm{In}\right) /$ Rhenium $\left({ }^{187} \mathrm{Re}\right)$ were used as internal standards. The accuracy of digestion and analysis protocol was checked using certified standards. SLR-4 for water samples, pine needle SRM-1575a, Moss II and Moss III (Steinnes et al., 1997) for moss samples, and lichen IAEA-336, pine needle SRM-1575a and peach leaves SRM-1547 for lichen samples. Measured values were within the certified ranges. Similar recoveries (from $-20 \%$ to $0 \%$ ) were observed for the two protocols used for lichen and moss series, although using different acid mixtures.

The soil and bedrock samples were fused in Pt crucibles by $\mathrm{LiBO}_{2}$ at $980{ }^{\circ} \mathrm{C}$ in an automatic tunnel oven. Samples were mineralised by a $\mathrm{HNO}_{3} / \mathrm{H}_{2} \mathrm{O}_{2} /$ glycerol mixture and analysed by ICP-MS (CRPG, Nancy, France). A blank and 5 international geostandards (Govindaraju, 1994) were prepared and analysed with each sample batch. Recovery efficiency on geostandard was $>85 \%$ for all elements.

\subsection{Statistical analysis}

Statistical analyses were performed using the R software and the ade4 and ggplot2 packages. Significant differences were tested using the Kruskal-Wallis (KW) test $(\alpha=0.05)$. The principal component analysis (PCA) was performed on standard score TM data.

\section{Results}

\subsection{Trace metal content in mosses and lichens}

Trace metal contents in biomonitors are presented in Table 2 . The measured TM concentrations in mosses were consistent with lower bound of the values reported for France and the rest of Europe in 2005 and 2010 (Harmens et al., 2010), except for $\mathrm{Cr}$ in SP $11, \mathrm{~Pb}$ in EPC 08 and $\mathrm{Zn}$ for all the sites. The data did not shown exceeding values like in Belgium and countries of Eastern Europe (e.g. Bulgaria, Serbia or Slovakia), in relation to the site location far from direct TM sources, reflecting background levels. For lichens, the TM concentrations fell between "very high naturality" class to "low naturality/alteration" class following the scale defined by Bargagli and Nimis (2002), except for Al and Fe in SP 11 with "middle alteration" class. Manganese concentrations were significantly (KW, $p<0.05$ ) higher in mosses compared to lichens in the three sites, as well as $\mathrm{Pb}$ and $\mathrm{Ni}$ in EPC 08, Cs in EPC 63, and $\mathrm{Cu}$ and $\mathrm{Ni}$ in SP 11. On the contrary, $\mathrm{Al}, \mathrm{Fe}, \mathrm{Cr}, \mathrm{As}, \mathrm{Sn}$ and $\mathrm{Sb}$ concentrations were significantly higher in lichens compared to mosses for the three sites (KW, $p<0.05$, except for $\mathrm{Al}$ and $\mathrm{Cr}$ in SP 11). The rare earth elements concentrations were similar for lichens and mosses for a given site. The REE range fall into the values published in the literature and reported in Dołęgowska and Migaszewski (2013) for Poland, Scandinavia and Canada.

\subsection{Trace metal enrichments in mosses and lichens}

The enrichment factors (EF) in biomonitors were calculated for each element $\mathrm{X}$ following Equation (1) using $\mathrm{Al}$ as the normalising element and the local bedrock as the reference (Bargagli, 1995).

$\mathrm{EF}=\frac{(\mathrm{X} / \mathrm{Al})_{\text {Biomonitor }}}{(\mathrm{X} / \mathrm{Al})_{\text {Local Bedrock }}}$

The dispersion of EF values calculated in the three sites is presented in Fig. 2. In the three sites, calculated EF were above 2 for both biomonitors for all studied elements except for Fe and V. The calculated enrichment factors for most elements were higher in EPC 08 compared to the other study sites. For lichens, based on the median value (Fig. 2), EF increased following this order: $\mathrm{Fe}<\mathrm{V}<\mathrm{Cr}<\mathrm{Cs}<\mathrm{Mn}<\mathrm{Ni}<\mathrm{As}<\mathrm{Sn}<\mathrm{Cd}<\mathrm{Pb}<\mathrm{Zn}<\mathrm{Cu}<\mathrm{Sb}$. The increase order of $\mathrm{EF}$ for mosses was close to the lichen one: $\mathrm{Fe}<\mathrm{V}<\mathrm{Cr}<\mathrm{As}<\mathrm{Ni}<\mathrm{Sn}<\mathrm{Mn}<\mathrm{Cu}<\mathrm{Cs}<\mathrm{Sb}<\mathrm{Cd}<\mathrm{Zn}<\mathrm{Pb}$. If sites were considered individually, EF were significantly higher in mosses compared to lichens in the three sites for $\mathrm{Mn}, \mathrm{Pb}, \mathrm{Cs}, \mathrm{Cu}$, and $\mathrm{Ni}(\mathrm{KW}, p<0.01)$.

\subsection{Association of TM in forest ecosystem compartments}

The principal component analysis (PCA) based on TM concentrations in biomonitors and deposition is shown on Fig. 3. The first axis, explaining $40 \%$ of the data variance, discriminated biomonitors (lichens, mosses) and deposition (BD and TF). The lithogenic elements with low $\mathrm{EF}$ ( $\mathrm{Al}, \mathrm{Fe}, \mathrm{Cr}$ or $\mathrm{V}$ ), as well as two micronutrients, $\mathrm{Cu}$ and $\mathrm{Ni}$ were the main contributors to this axis. The second axis, which explained only $15 \%$ of the data variance discriminated lichens and BD from mosses and TF. Lead, Mn, Zn and Sb were the main contributors for this axis.

The TM signatures were further investigated using the ratios of the normalised concentration to $\mathrm{Al}$ (Fig. 4a and b). These ratios were lower in soil and bedrock compared to other compartments in 
Table 2

Mean and standard deviation (SD) of the concentration $\left(\mu \mathrm{g} \mathrm{g}^{-1}\right)$ of the studied TM and REE elements in the different ecosystem compartments.

\begin{tabular}{|c|c|c|c|c|c|c|c|c|c|c|c|c|c|c|c|c|c|c|c|c|c|c|}
\hline & & $n$ & & $\mathrm{Al}$ & As & $\mathrm{Cd}$ & $\mathrm{Cr}$ & Cs & $\mathrm{Cu}$ & $\mathrm{Fe}$ & $\mathrm{Mn}$ & $\mathrm{Ni}$ & $\mathrm{Pb}$ & $\mathrm{Sb}$ & Sn & $\mathrm{V}$ & $\mathrm{Zn}$ & La & $\mathrm{Ce}$ & $\mathrm{Nd}$ & $\mathrm{Sm}$ & $\mathrm{Yb}$ \\
\hline \multirow[t]{10}{*}{ EPC 08} & Lichen $\left(\mu \mathrm{g} \mathrm{g}^{-1}\right)$ & 5 & Mean & 807.21 & 0.49 & 0.47 & 2.33 & 0.13 & 7.04 & 523.59 & 41.80 & 1.81 & 5.25 & 0.28 & 0.64 & 1.81 & 83.45 & 0.574 & 0.970 & 0.388 & 0.076 & 0.030 \\
\hline & & & $S D$ & 554.15 & 0.24 & 0.25 & 0.67 & 0.07 & 1.28 & 275.34 & 9.59 & 0.44 & 0.83 & 0.05 & 0.06 & 0.86 & 35.17 & 0.309 & 0.586 & 0.226 & 0.044 & 0.020 \\
\hline & $\operatorname{Moss}\left(\mu \mathrm{g} \mathrm{g}^{-1}\right)$ & 4 & Mean & 197.41 & 0.13 & 0.22 & 1.14 & 0.18 & 6.28 & 241.47 & 212.42 & 2.50 & 9.44 & 0.21 & 0.40 & 1.64 & 46.05 & 0.287 & 0.433 & 0.189 & 0.035 & 0.010 \\
\hline & & & $S D$ & 27.20 & 0.02 & 0.03 & 0.12 & 0.04 & 0.34 & 27.41 & 68.25 & 0.29 & 1.47 & 0.02 & 0.05 & 0.14 & 0.98 & 0.029 & 0.043 & 0.022 & 0.002 & 0.001 \\
\hline & Bulk deposition $\left(\mu \mathrm{g} \mathrm{L}^{-1}\right)$ & 14 & Mean & 6.86 & 0.09 & 0.09 & 0.07 & 0.01 & 0.88 & 4.14 & 3.24 & 0.44 & 0.70 & 0.12 & 0.10 & 0.35 & 12.04 & $<\mathrm{QL}$ & $<\mathrm{QL}$ & $<\mathrm{QL}$ & $<\mathrm{QL}$ & $<\mathrm{QL}$ \\
\hline & & & $S D$ & 6.73 & 0.05 & 0.15 & 0.05 & 0.03 & 0.60 & 3.99 & 1.84 & 0.23 & 0.59 & 0.07 & 0.27 & 0.17 & 8.64 & $<\mathrm{QL}$ & $<\mathrm{QL}$ & $<\mathrm{QL}$ & $<\mathrm{QL}$ & $<\mathrm{QL}$ \\
\hline & Throughfall $\left(\mu \mathrm{g} \mathrm{L}^{-1}\right)$ & 14 & Mean & 24.47 & 0.23 & 0.06 & 0.15 & 0.05 & 1.64 & 12.65 & 157.31 & 0.67 & 3.09 & 0.85 & 20.00 & 0.40 & 29.95 & 0.011 & 0.020 & 0.010 & $<\mathrm{QL}$ & $<\mathrm{QL}$ \\
\hline & & & $S D$ & 22.08 & 0.50 & 0.08 & 0.11 & 0.05 & 1.34 & 7.58 & 105.61 & 0.62 & 1.96 & 0.41 & 73.68 & 0.16 & 38.24 & 0.006 & 0.012 & 0.007 & $<\mathrm{QL}$ & $<\mathrm{QL}$ \\
\hline & Soil and bedrock $\left(\mu \mathrm{g} \mathrm{g}^{-1}\right)$ & 5 & Mean & $77,745.58$ & 44.01 & 0.42 & 103.08 & 5.84 & 30.11 & $32,466.44$ & 280.51 & 11.79 & 37.11 & 2.20 & 3.78 & 110.16 & 48.12 & 26.254 & 53.208 & 21.778 & 4.427 & 3.495 \\
\hline & & & $S D$ & $11,504.66$ & 6.52 & 0.10 & 9.40 & 0.73 & 4.30 & 2268.72 & 88.46 & 4.42 & 16.42 & 0.29 & 1.36 & 9.28 & 10.15 & 2.017 & 6.560 & 1.944 & 0.414 & 0.143 \\
\hline \multirow[t]{10}{*}{ EPC 63} & Lichen $\left(\mu \mathrm{g} \mathrm{g}^{-1}\right)$ & 8 & Mean & 988.32 & 0.67 & 0.07 & 2.22 & 0.34 & 6.88 & 759.13 & 25.14 & 1.26 & 2.51 & 0.12 & 0.33 & 2.36 & 30.00 & 0.815 & 1.499 & 0.581 & 0.106 & 0.031 \\
\hline & & & $S D$ & 299.36 & 0.35 & 0.04 & 1.00 & 0.20 & 2.11 & 262.20 & 3.96 & 0.54 & 1.14 & 0.03 & 0.16 & 0.54 & 18.07 & 0.139 & 0.322 & 0.109 & 0.022 & 0.007 \\
\hline & $\operatorname{Moss}\left(\mu \mathrm{g} \mathrm{g}^{-1}\right)$ & 12 & Mean & 386.13 & 0.14 & 0.10 & 0.84 & 0.64 & 3.78 & 280.13 & 172.81 & 1.12 & 2.27 & 0.06 & 0.11 & 1.05 & 34.72 & 0.370 & 0.707 & 0.300 & 0.056 & 0.014 \\
\hline & & & $S D$ & 139.01 & 0.03 & 0.07 & 0.23 & 0.18 & 0.85 & 101.98 & 39.69 & 0.28 & 0.68 & 0.02 & 0.05 & 0.31 & 13.30 & 0.127 & 0.190 & 0.072 & 0.013 & 0.003 \\
\hline & Bulk deposition $\left(\mu \mathrm{g} \mathrm{L}^{-1}\right)$ & 14 & Mean & 8.86 & 0.10 & 0.06 & 0.08 & 0.01 & 0.84 & 4.84 & 3.22 & 0.62 & 0.24 & 0.06 & 0.04 & 0.19 & 43.32 & $<\mathrm{QL}$ & $<\mathrm{QL}$ & $<\mathrm{QL}$ & $<\mathrm{QL}$ & $<\mathrm{QL}$ \\
\hline & & & $S D$ & 18.71 & 0.07 & 0.10 & 0.06 & 0.01 & 0.68 & 10.49 & 5.07 & 0.96 & 0.26 & 0.04 & 0.07 & 0.08 & 59.44 & $<\mathrm{QL}$ & $<\mathrm{QL}$ & $<\mathrm{QL}$ & $<\mathrm{QL}$ & $<\mathrm{QL}$ \\
\hline & Throughfall $\left(\mu \mathrm{g} \mathrm{L}^{-1}\right)$ & 14 & Mean & 37.29 & 1.24 & 0.03 & 0.27 & 0.28 & 1.96 & 16.43 & 131.34 & 0.61 & 4.09 & 1.05 & 0.48 & 0.36 & 24.21 & 0.025 & 0.060 & 0.031 & $<\mathrm{QL}$ & $<\mathrm{QL}$ \\
\hline & & & $S D$ & 16.10 & 1.89 & 0.02 & 0.15 & 0.26 & 0.78 & 6.81 & 120.42 & 0.29 & 3.16 & 0.72 & 1.11 & 0.14 & 14.73 & 0.008 & 0.021 & 0.014 & $<\mathrm{QL}$ & $<\mathrm{QL}$ \\
\hline & Soil and bedrock $\left(\mu \mathrm{g} \mathrm{g}^{-1}\right)$ & 5 & Mean & $94,505.15$ & 11.19 & 0.57 & 72.07 & 3.08 & 19.95 & $63,637.53$ & 1648.97 & 28.91 & 37.54 & 1.29 & 3.39 & 141.47 & 140.48 & 58.426 & 119.370 & 42.034 & 7.432 & 2.456 \\
\hline & & & $S D$ & $13,935.28$ & 2.90 & 0.13 & 16.71 & 0.44 & 8.29 & $14,176.41$ & 204.51 & 9.58 & 30.59 & 1.03 & 0.61 & 42.95 & 13.40 & 14.563 & & & 1.995 & 0.606 \\
\hline \multirow[t]{10}{*}{ SP 11} & Lichen $\left(\mu \mathrm{g} \mathrm{g}^{-1}\right)$ & 5 & Mean & 2364.13 & 0.68 & 0.07 & 3.69 & 0.26 & 4.66 & 1347.08 & 29.29 & 1.72 & 2.28 & 0.12 & 0.38 & 4.13 & 22.05 & 1.354 & 2.647 & 1.136 & 0.216 & 0.081 \\
\hline & & & $S D$ & 1054.30 & 0.18 & 0.01 & 1.31 & 0.13 & 0.92 & 595.59 & 14.65 & 0.54 & 1.47 & 0.05 & 0.16 & 1.96 & 9.62 & 0.606 & 1.192 & 0.523 & 0.098 & 0.038 \\
\hline & $\operatorname{Moss}\left(\mu \mathrm{g} \mathrm{g}^{-1}\right)$ & 6 & Mean & 1633.35 & 0.39 & 0.17 & 3.28 & 0.28 & 8.20 & 989.07 & 97.40 & 3.25 & 3.67 & 0.05 & 0.14 & 3.08 & 24.31 & 1.006 & & 1.0 & 0.224 & 0.064 \\
\hline & & & $S D$ & 712.37 & 0.12 & 0.07 & 1.26 & 0.12 & 2.68 & 454.91 & 29.72 & 1.05 & 1.15 & 0.02 & 0.06 & 1.29 & 8.62 & 0.387 & 0.803 & 0.448 & 0.093 & 0.028 \\
\hline & Bulk deposition $\left(\mu \mathrm{g} \mathrm{L}^{-1}\right)$ & 14 & Mean & 4.23 & 0.12 & 0.02 & 0.09 & 0.01 & 1.06 & 2.43 & 2.53 & 0.83 & 0.23 & 0.47 & 0.13 & 0.27 & 23.92 & $<\mathrm{QL}$ & $<\mathrm{QL}$ & $<\mathrm{QL}$ & $<\mathrm{QL}$ & $<\mathrm{QL}$ \\
\hline & & & $S D$ & 3.04 & 0.08 & 0.02 & 0.06 & 0.01 & 1.05 & 2.15 & 2.07 & 1.04 & 0.16 & 1.19 & 0.31 & 0.19 & 29.42 & $<\mathrm{Q}$ & $<Q$ & $<Q$ & $<\mathrm{QL}$ & $<\mathrm{QL}$ \\
\hline & Throughfall $\left(\mu \mathrm{g} \mathrm{L}^{-1}\right)$ & 14 & Mean & 50.33 & 0.24 & 0.05 & 0.16 & 0.02 & 2.80 & 22.71 & 46.76 & 0.94 & 7.85 & 1.53 & 0.42 & 0.50 & 16.41 & 0.037 & 0.102 & 0.051 & $<\mathrm{QL}$ & $<\mathrm{QL}$ \\
\hline & & & $S D$ & 27.58 & 0.12 & 0.03 & 0.09 & 0.02 & 1.67 & 7.89 & 16.69 & 0.42 & 3.80 & 0.79 & 0.8 & 0.23 & 13.36 & 0.0 & 0.050 & 0.0 & $<\mathrm{QL}$ & $<\mathrm{QL}$ \\
\hline & Soil and bedrock $\left(\mu \mathrm{g} \mathrm{g}^{-1}\right)$ & 5 & Mean & $70,064.38$ & 10.15 & 0.38 & 106.50 & 9.11 & 17.70 & $37,905.26$ & 446.71 & 43.09 & 24.45 & 0.72 & 2.89 & 109.20 & 97.45 & 35.610 & 69.210 & 30.408 & 5.928 & 2.485 \\
\hline & & & $S D$ & 6633.53 & 1.03 & 0.10 & 2.88 & 1.37 & 8.75 & 1177.20 & 258.59 & 5.94 & 4.22 & 0.09 & 0.11 & 6.06 & 6.66 & 1.697 & 2.839 & 1.232 & 0.375 & 0.056 \\
\hline
\end{tabular}




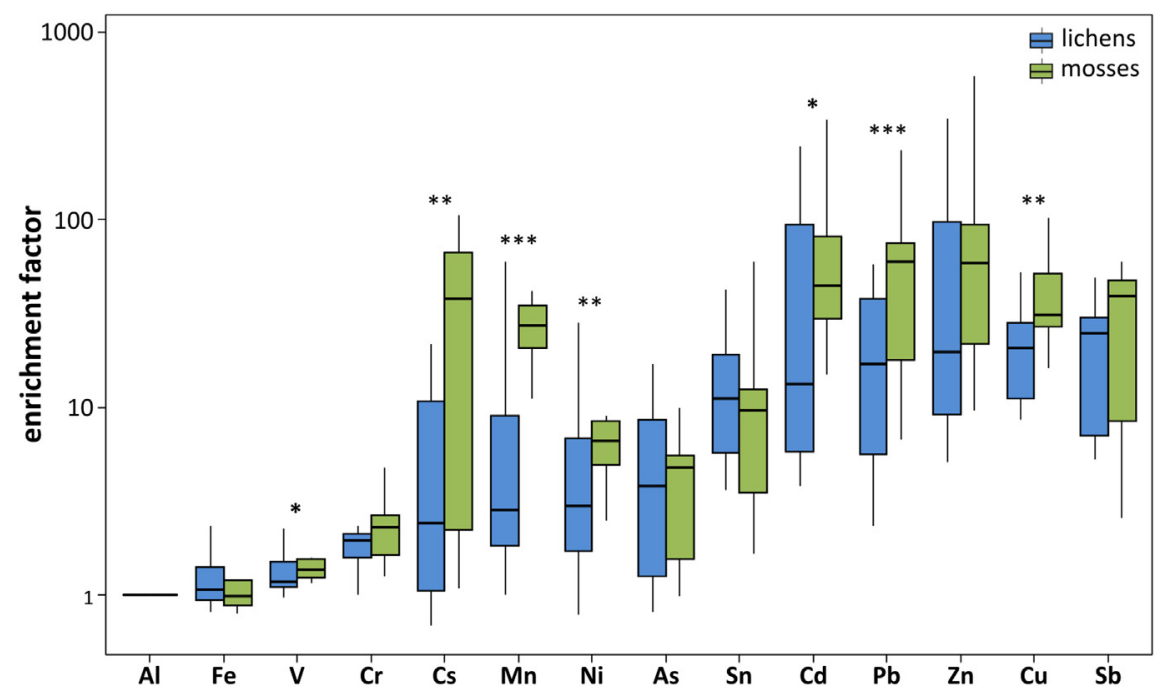

Fig. 2. Boxplot of enrichment factors in lichens $(n=18)$ and mosses $(n=22)$ using $\mathrm{Al}$ and local bedrock normalisation $\left({ }^{*} p<0.05\right.$, ${ }^{* *} p<0.01$, ${ }^{* * *} p<0.001$, KW test).

the forest ecosystem in relation to the high $\mathrm{Al}$ content in soil. The ratios were lower in biomonitors compared to both bulk deposition and throughfall. For elements contributing to ACP axis $1(\mathrm{Cu}$ and $\mathrm{Ni}$, Figs. 3 and $4 \mathrm{a}$ ), the ratios measured in biomonitors aligned with those measured in BD and TF. A decrease of these ratios from BD to TF suggested the direct uptake of these elements by the forest canopy. Ratios in lichens were lower compared to mosses. For elements which contributed to axis 2 ( $\mathrm{Mn}$ and $\mathrm{Zn}$ given as examples, Figs. 3 and 4b), ratios differed in lichens and mosses. For these elements, the TM signature in mosses align with the throughfall one whereas the TM signature in lichens is close to the BD one (Fig. 4b).

\subsection{REE signature in forest ecosystem compartments}

In order to identify REE origin in biomonitors, we plotted a diagram showing $\mathrm{La} / \mathrm{Sm}$ vs $\mathrm{La} / \mathrm{Yb}$ for lichens, mosses and local bedrock (Fig. 5a). The combination of these two ratios allowed discriminating the local bedrocks from the three study sites: the La/
$\mathrm{Yb}$ ratio is different for the three locations. The La/Sm ratio is similar for SP 11 and EPC 08 (around 6) but is higher for EPC 63 (around 8). In EPC 63 and SP 11, the REE ratios measured in lichens and mosses are close to the bedrock ones. In EPC 08, the signature measured in the biomonitors differs from the local bedrock, with higher ratios measured in the biomonitors. In SP 11 and EPC 63, the light $\mathrm{REE}$ ratio $(\mathrm{La} / \mathrm{Sm})$ is higher in lichens compared to mosses, and is closer to the one measured in the local bedrock, whereas the La/ $\mathrm{Yb}$ do not discriminate lichens from mosses. This is not verified in EPC 08 site, where the La/Yb ratio, and not the La/Sm ratio, discriminates lichens and mosses. In all sites, REE ratios measured in lichens are closer to the bedrock ones compared to the one measured in mosses. This is also shown when looking at light REE ratios ( $\mathrm{La} / \mathrm{Ce}$ vs $\mathrm{La} / \mathrm{Nd}$ ) in biomonitors, TF and local bedrock (Fig. 5b-d). In all sites, lichen signatures for these ratios are close to the bedrock one, whereas mosses show an intermediate signature between local bedrock and TF. This is less clear in EPC 08, where the REE signature measured in TF covers a wider range of values.

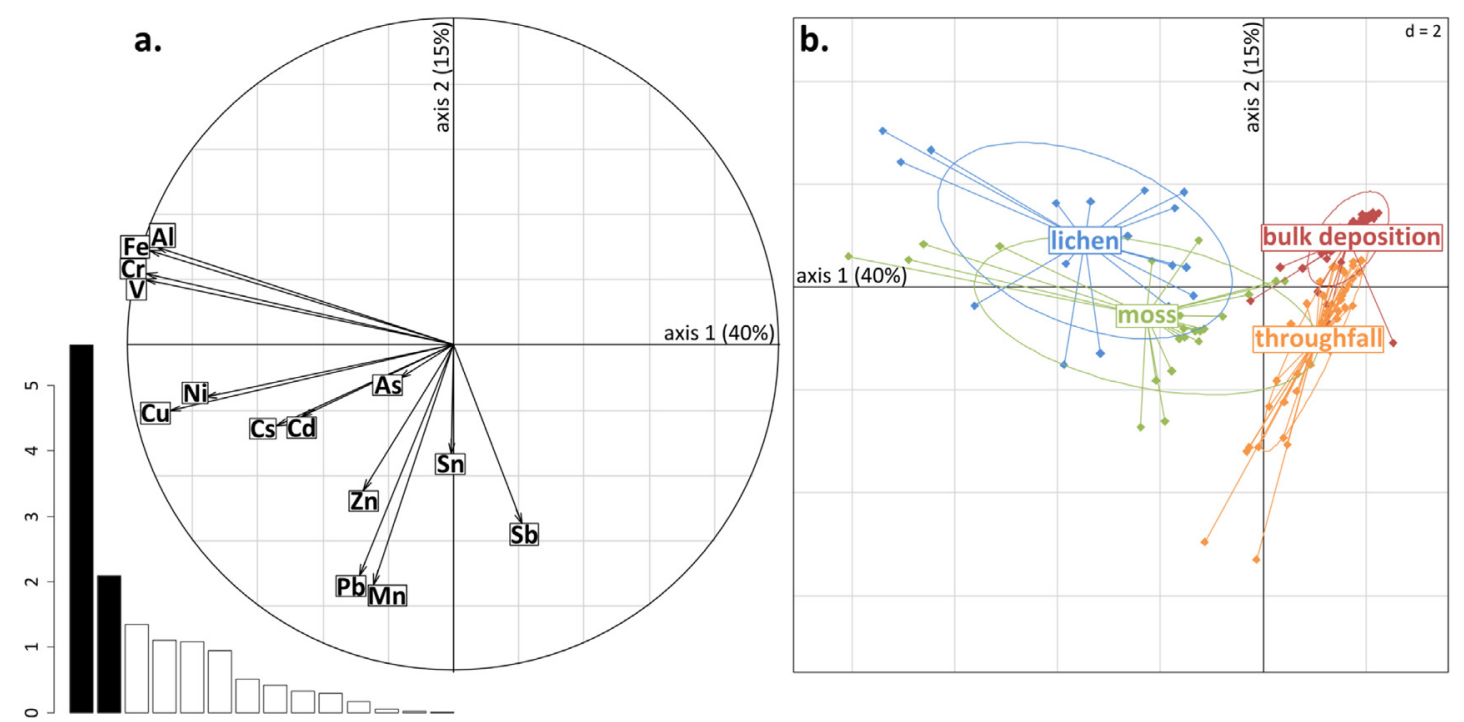

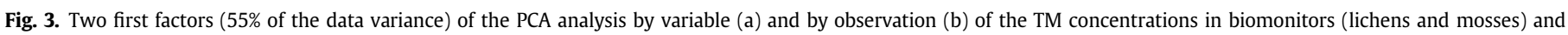
atmospheric deposition (bulk deposition and throughfall). 

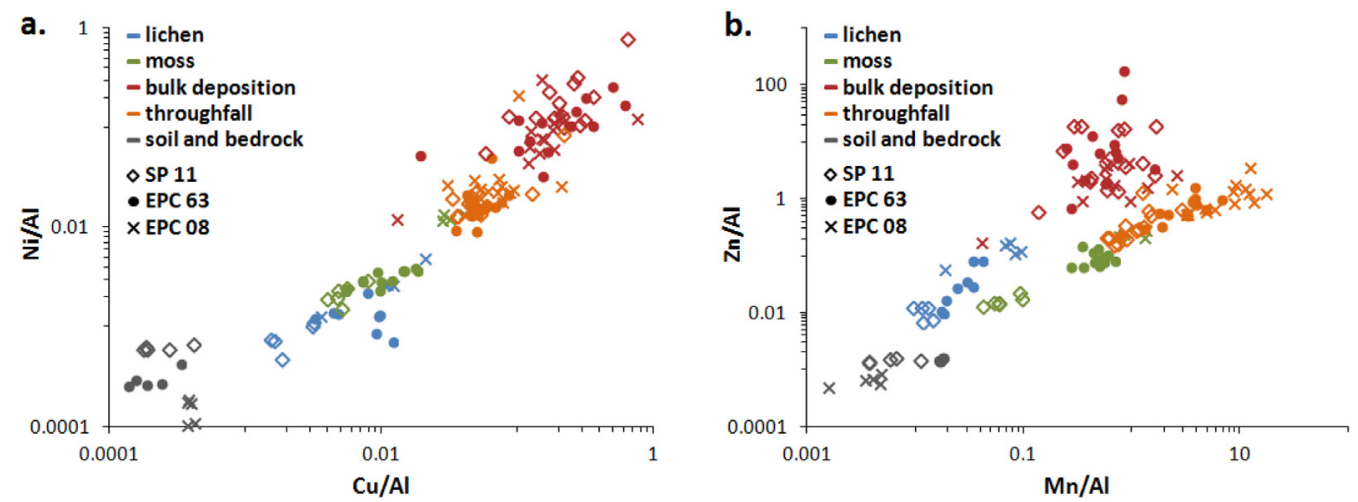

Fig. 4. Trace metal signature in the lichens, mosses, bulk deposition, throughfall and local bedrock: $\mathrm{Ni} / \mathrm{Al}$ vs $\mathrm{Cu} / \mathrm{Al}$ (a) and $\mathrm{Zn} / \mathrm{Al}$ vs $\mathrm{Mn} / \mathrm{Al}(\mathrm{b})$.

\section{Discussion}

\subsection{Bioaccumulation of TM deposition by lichens and mosses}

Since both lichens and mosses are widely used as biomonitors, their respective bioaccumulation capabilities have been investigated in various environmental contexts (Berg et al., 1995; Garty, 2001; Bargagli et al., 2002; Szczepaniak and Biziuk, 2003). In highly contaminated contexts and using transplant of lichen and moss bags (Basile et al., 2008; Bargagli et al., 2002), higher accumulation by mosses was observed. The authors suggest that lichens are more sensitive to environmental factors, like rainfall, and that elements contained in lichens are more likely to be leached. In the context of this study (low contaminated forest ecosystems), higher concentrations of lithogenic elements ( $\mathrm{Al}, \mathrm{Fe}, \mathrm{Cr}$ and $\mathrm{As}$ ) were measured in lichens compared to mosses, the latter being enriched in $\mathrm{Mn}$ in all sites, and $\mathrm{Pb}$ and $\mathrm{Ni}$ in two of the three sites. Higher $\mathrm{EF}$ values were calculated for $\mathrm{Cs}, \mathrm{Mn}, \mathrm{Pb}$ and $\mathrm{Cu}$ in mosses and therefore higher contamination would be identified if mosses were considered compared to lichens (Fig. 2). This observation supports the fact that terricolous mosses were not influenced by direct elemental transfer from soils, which would have induced high concentration of lithogenic elements in terricolous mosses. The higher concentration for $\mathrm{Al}, \mathrm{Fe}, \mathrm{Cr}$ and As observed for lichens could be related to different mechanisms. Since we sampled corticulous lichens, transfer from the soil cannot explain this enrichment. Tree barks are known to reflect TM atmospheric deposition and accumulate particulate deposition, including lithogenic minerals (Faggi et al., 2011; Gueguen et al., 2012). Transfer from barks or stemflow to lichens has been observed for major elements, but appears limited for trace elements (Prussia and Killingbeck, 1991; Sloof and Wolterbeek, 1993). In the low contamination context of our study, the higher concentrations of lithogenic elements ( $\mathrm{Al}, \mathrm{Fe}, \mathrm{Cr}$ ) and the relative loss of some TM $(\mathrm{Cu}, \mathrm{Ni}$, Fig. 3a) by lichens compared to
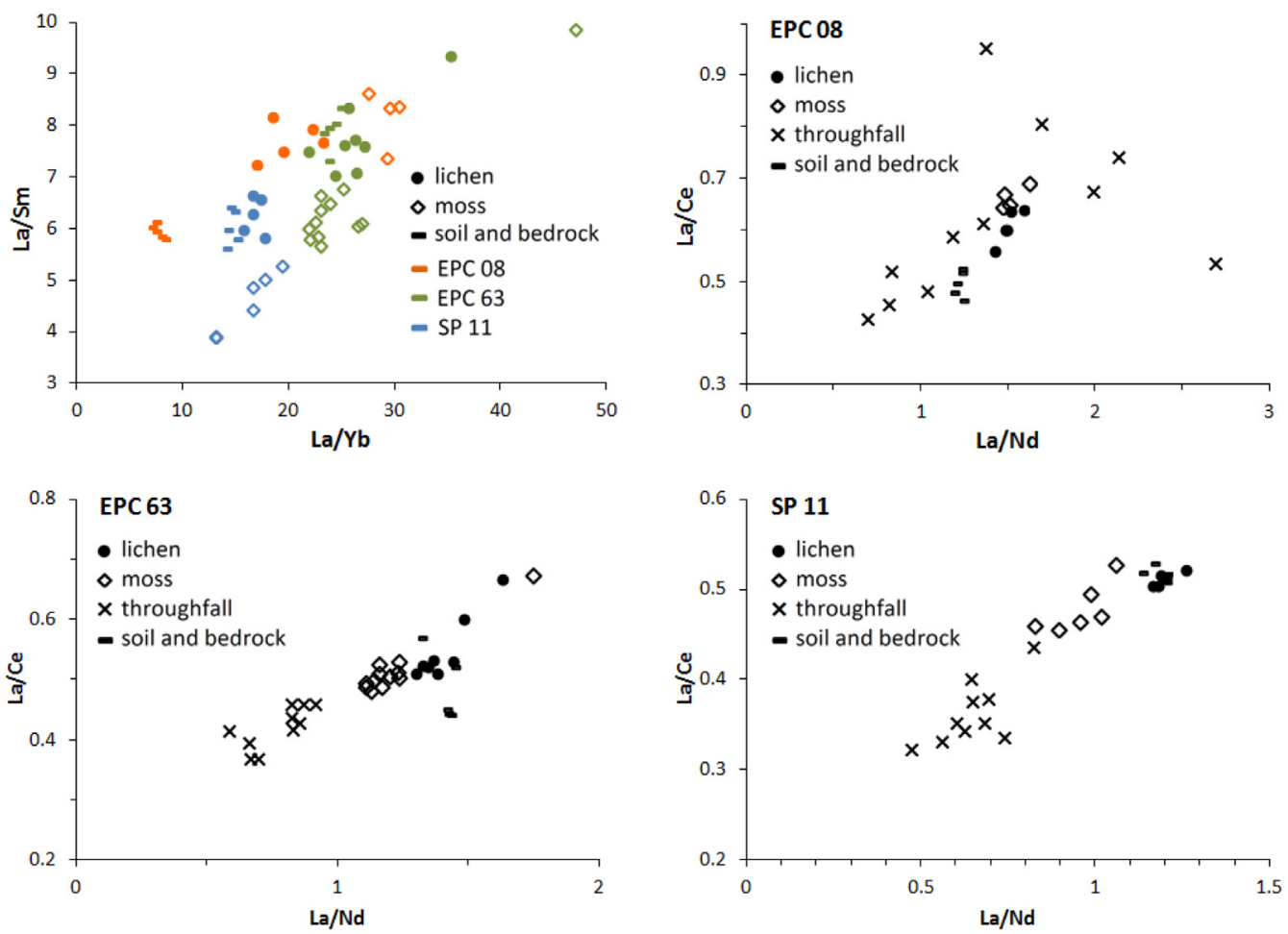

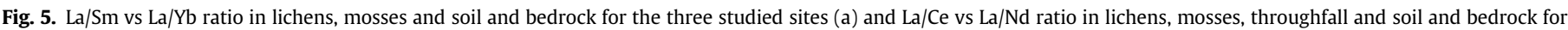
EPC 08 (b), EPC 63 (c) and SP 11 (d). 
mosses and deposition were more likely due to higher selective accumulation of lithogenic elements by lichens or longer accumulation time. In the case of mosses, the concentrations of TM in biomonitors vary with time and selective loss of elements has been observed (Boquete et al., 2011). The longer life span of lichens and therefore the longer accumulation time compared to mosses could explain their higher concentration of lithogenic elements (Catinon et al., 2009).

\subsection{Spatial integration of biomonitors}

The REE ratios ( $\mathrm{La} / \mathrm{Sm}$ vs $\mathrm{La} / \mathrm{Yb}$ ) have been used to investigate the origin of TM deposition in environmental archive, like peat (Aubert et al., 2006). In this study, distinct values of the La/Sm vs La/ $\mathrm{Y}$ ratios were observed for the soils and bedrocks of the three studied sites, allowing the identification of the local dust signature (Fig. 5a) for the different mountainous massifs. This specific signature was recorded by both mosses and lichens, highlighting a regional integration of TM atmospheric deposition by biomonitors. Trace metal dispersion range depend on the chemical form during emission and transport (Chester et al., 1993; Desboeufs et al., 1999; Colbeck, 2008). While some TM can be transported for long distance, the influence of TM emissions hotspots like cities and factories rapidly decrease within kilometres (Aznar et al., 2008; Cloquet et al., 2006).

In the Pyrenees (SP 11), higher concentration of $\mathrm{Al}$ and $\mathrm{Fe}$ and REE were measured in mosses and lichens compared to the other sites, in accordance with the high deposition of these elements in this area (Gandois et al., 2010). This is potentially related to the former mining activity in the area. In the North-East of France (EPC 08, Fig. 4a and b), REE signatures in TF was more dispersed, and higher La/Sm ratios were measured in biomonitors compared to the local soil and bedrock (Fig. 4b). Higher La/Sm ratio could indicate industrial deposition, as measured in particulate matter originating from steel plants by Gueguen et al. (2012). In this site located in an industrial area, higher EF compared to other sites were recorded by both lichens and mosses for many elements ( $\mathrm{Zn}, \mathrm{Sr}, \mathrm{Pb}, \mathrm{V}, \mathrm{Cr}, \mathrm{Ni}, \mathrm{Sn}$ and $\mathrm{Co}$ ), reflecting relatively more anthropogenic metallic atmospheric deposition already evidenced (Gandois et al., 2010) and registered in surface layers of the soils (Hernandez et al., 2003).

\subsection{Influence of vegetation on biomonitor records}

Both TM rand REE ratios in biomonitors highlighted the higher influence of throughfall on moss composition compared to lichens. Mosses were enriched in Mn compared to lichens, and in some sites, in $\mathrm{Pb}, \mathrm{Ni}$, and $\mathrm{Cu}$ (Fig. 2). The $\mathrm{Mn} / \mathrm{Al}$ and $\mathrm{Zn} / \mathrm{Al}$ ratios in mosses aligned with the throughfall ones, and showed a relative enrichment in Mn compared to $\mathrm{Zn}$ (Fig. 4b). In forested ecosystems, throughfall composition reflects processes occurring on the canopy, including elemental recretion, direct uptake, as well as accumulation and leaching of dry deposition (Lindberg and Lovett, 1992; Probst et al., 1992; Balestrini et al., 2007; Gandois et al., 2010). The Mn enrichment of mosses reflects the already observed high Mn cycling in forested ecosystem and recretion by the canopy (Petty et Lindberg, 1990; Gandois et al., 2010), and highlights the influence of canopy on moss record (Schilling and Lehman, 2002). Trace metals that are mostly deposited in the form of dry deposition, including $\mathrm{Al}, \mathrm{Fe}$ and $\mathrm{Pb}$, are enriched in $\mathrm{TF}$, as a consequence of dissolution of accumulated dry deposition on the canopy. For these elements, TF is a proxy of both wet and dry deposition (Hou et al., 2005; Gandois and Probst, 2012). In mosses, the REE ratios reflected both TF composition and the local bedrock (Fig. 5), while lichen closely reflected the local bedrock composition. This add to the evidence that in forested ecosystems mosses also reflect the influence of accumulation of dust deposition on forest canopy and following dissolution and leaching in TF. The integration of TM from other sources than atmospheric deposition to mosses has been highlighted by Steinnes (1995), and included transfer from vascular plants, direct uptake from soil, and ion exchange with deposition. All these reasons have been cited by Aboal et al. (2010) to explain the lack of correlation between TM content in mosses and atmospheric deposition measured in BD. Our results suggest that in forest ecosystems, the lack of correlation between mosses and BD is related to the canopy influence, mosses reflecting TF composition. Depending on the considered element, this includes recretion by the canopy or dissolution of accumulated dry deposition. When compared to lichens, mosses reflect the local below-canopy environment and integrate wider spatial influence due to dust deposition. In survey networks, mosses are collected under the forest cover to assess TM deposition (Harmens et al., 2012). This study confirms that below canopy collected mosses do not reflect bulk deposition.

\section{Conclusion}

This study combined the TM and REE signatures in biomonitors (mosses and lichens) and in various compartments of the forest ecosystem (bulk deposition and throughfall, soil and bedrock), in order to study the elemental transfers between compartments.

The similar REE ratios measured in soil and local bedrock and biomonitors for each mountainous area showed that lichens and mosses integrated a regional atmospheric signal, including both soil derived and industrially influenced atmospheric deposition. Based on EF, comparable contamination diagnostics could be addressed using lichens and mosses, with the exception of Cs, Mn, $\mathrm{Ni}, \mathrm{Pb}$ and $\mathrm{Cu}$. Different accumulation of TM by lichens and mosses were attributed to a different influence of forest ecosystems on the two biomonitors. Mosses reflected the TF composition whereas lichens were less influenced by the forest canopy. These organisms were enriched in micronutrients highly cycled in forested ecosystems and leached by the forest cover, like Mn. In contrast to lichens, mosses were also enriched in element likely transported in the form of dry deposition ( $\mathrm{Cs}, \mathrm{Pb}, \mathrm{Cu}, \mathrm{REE}$ ), which accumulate on forest canopy. They are more influenced than lichens by the local undercanopy environment and integrate a wider spatial signal in relation to dust deposition on the canopy. When collected in forested ecosystems, mosses reflect both atmospheric deposition and canopy influence.

\section{Acknowledgements}

This project benefited from a financial support by ADEME (French Agency for Environment) and received logistic support from the ONF (French Forest board). The authors warmly thank the ONF staff for great help during field work, Manuel Nicolas for acceded to the RENECOFOR data, Frédéric Candaudap (GET, Université de Toulouse, UPS-CNRS-IRD) for ICP-MS analysis assistance.

\section{References}

Aboal, J.R., Fernández, J.A., Boquete, T., Carballeira, A., 2010. Is it possible to estimate atmospheric deposition of heavy metals by analysis of terrestrial mosses? Sci. Total Environ. 408, 6291-6297. http://dx.doi.org/10.1016/j.scitotenv. 2010.09.013.

Adriano, D.C., 2001. Trace Elements in Terrestrial Environments: Biogeochemistry, Bioavailability, and Risks of Metals. Springer, New York, p. 888.

Agnan, Y., Séjalon-Delmas, N., Probst, A., 2013. Comparing early twentieth century and present-day atmospheric pollution in SW France: a story of lichens. Environ. Pollut. 172, 139-148. http://dx.doi.org/10.1016/j.envpol.2012.09.008. 
Agnan, Y., Séjalon-Delmas, N., Probst, A., 2014. Origin and distribution of rare earth elements in various lichen and moss species over the last century in France. Sci. Total Environ. 487, 1-12. http://dx.doi.org/10.1016/j.scitotenv.2014.03.132.

Armstrong, R., Bradwell, T., 2010. Growth of crustose lichens: a review. Geogr. Ann. Ser. Phys. Geogr. 92, 3-17. http://dx.doi.org/10.1111/j.1468-0459.2010.00374.x.

Aubert, D., Le Roux, G., Krachler, M., Cheburkin, A., Kober, B., Shotyk, W., Stille, P., 2006. Origin and fluxes of atmospheric REE entering an ombrotrophic peat bog in Black Forest (SW Germany): evidence from snow, lichens and mosses. Geochim. Cosmochim. Acta 70, 2815-2826. http://dx.doi.org/10.1016 j.gca.2006.02.020.

Aubert, D., Stille, P., Probst, A., 2001. REE fractionation during granite weathering and removal by waters and suspended loads: $\mathrm{Sr}$ and $\mathrm{Nd}$ isotopic evidence. Geochim. Cosmochim. Acta 65, 387-406. http://dx.doi.org/10.1016/S00167037(00)00546-9.

Aznar, J.-C., Richer-Lafleche, M., Begin, C., Rodriguez, R., 2008. Spatiotemporal reconstruction of lead contamination using tree rings and organic soil layers. Sci. Total Environ. 407, 233-241. http://dx.doi.org/10.1016/j.scitotenv. 2008.09.044.

Balestrini, R., Arisci, S., Brizzio, M.C., Mosello, R., Rogora, M., Tagliaferri, A., 2007. Dry deposition of particles and canopy exchange: comparison of wet, bulk and throughfall deposition at five forest sites in Italy. Atmos. Environ. 41, 745-756. http://dx.doi.org/10.1016/j.atmosenv.2006.09.002.

Bargagli, R, 1995. The elemental composition of vegetation and the possible incidence of soil contamination of samples. Sci. Total Environ. 176, 121-128. http:/ dx.doi.org/10.1016/0048-9697(95)04838-3.

Bargagli, R., Monaci, F., Borghini, F., Bravi, F., Agnorelli, C., 2002. Mosses and lichens as biomonitors of trace metals. A comparison study on Hypnum cupressiforme and Parmelia caperata in a former mining district in Italy. Environ. Pollut. 116, 279-287. http://dx.doi.org/10.1016/S0269-7491(01)00125-7.

Bargagli, R., Nimis, P.L., 2002. Guidelines for the use of epiphytic lichens as biomonitors of atmospheric deposition of trace elements. In: Nimis, PI. Scheidegger, C., Wolseley, P.A. (Eds.), Monitoring with Lichens - Monitoring Lichens, NATO Science Series. Springer, Netherlands, pp. 295-299.

Basile, A., et al., 2008. Comparison of the heavy metal bioaccumulation capacity of an epiphytic moss and an epiphytic lichen. Environ. Pollut 151 (2), 401-407.

Beckett, R.P., Brown, D.H., 1984. The control of cadmium uptake in the lichen genus Peltigera. J. Exp. Bot. 35, 1071-1082. http://dx.doi.org/10.1093/jxb/35.7.1071.

Berg, T., Røyset, O., Steinnes, E., 1995. Moss (Hylocomium splendens) used as biomonitor of atmospheric trace element deposition: estimation of uptake efficiencies. Atmos. Environ. 29, 353-360. http://dx.doi.org/10.1016/1352-2310(94)00259-N.

Boileau, L.J.R., Beckett, PJ., Lavoie, P., Richardson, D.H.S., Nieboer, E., 1982. Lichen and mosses as monitors of industrial activity associated with uranium mining in northern Ontario, Canada-part 1: field procedures, chemical analysis and interspecies comparisons. Environ. Pollut. Ser. B Chem. Phys. 4, 69-84. http:/ dx.doi.org/10.1016/0143-148X(82)90036-2.

Boquete, M.T., Fernández, J.A., Aboal, J.R., Carballeira, A., 2011. Analysis of tempora variability in the concentrations of some elements in the terrestrial moss Pseudoscleropodium purum. Environ. Exp. Bot. 72, 210-216. http://dx.doi.org 10.1016/j.envexpbot.2011.03.002.

Catinon, M., Ayrault, S., Clocchiatti, R., Boudouma, O., Asta, J., Tissut, M., Ravanel, P. 2009. The anthropogenic atmospheric elements fraction: a new interpretation of elemental deposits on tree barks. Atmos. Environ. 43, 1124-1130. http:/ dx.doi.org/10.1016/j.atmosenv.2008.11.004.

Chauvel, C., Jahn, B.-M., 1984. Nd-Sr isotope and REE geochemistry of alkali basalts from the Massif Central, France. Geochim. Cosmochim. Acta 48, 93-110. http:/ dx.doi.org/10.1016/0016-7037(84)90352-1.

Chester, R., Murphy, K.J.T., Lin, F.J., Berry, A.S., Bradshaw, G.A., Corcoran, P.A., 1993 Factors controlling the solubilities of trace metals from non-remote aerosols deposited to the sea surface by the "dry" deposition mode. Mar. Chem. 42, 107-126. http://dx.doi.org/10.1016/0304-4203(93)90241-F.

Cloquet, C., Carignan, J., Libourel, G., 2006. Atmospheric pollutant dispersion around an urban area using trace metal concentrations and $\mathrm{Pb}$ isotopic compositions in epiphytic lichens. Atmos. Environ. 40, 574-587. http://dx.doi.org/10.1016/ j.atmosenv.2005.09.073.

Colbeck, I., 2008. Environmental Chemistry of Aerosols. Blackwell Pub.

Desboeufs, K.V., Losno, R., Vimeux, F., Cholbi, S., 1999. The pH-dependent dissolution of wind-transported Saharan dust. J. Geophys. Res. Atmos. 104, 21287-21299. http://dx.doi.org/10.1029/1999JD900236.

Dołegowska, Sabina, Migaszewski, Zdzisław M., 2013. Anomalous concentrations of rare earth elements in the moss-soil system from south-central Poland. Environ. Pollut. 178, 33-40.

During, H.J., 1979. Life strategies of bryophytes: a preliminary review. Lindbergia 5 , 2-18. http://dx.doi.org/10.2307/20149317.

Faggi, A.M., Fujiwara, F., Anido, C., Perelman, P.E., 2011. Use of tree bark for comparing environmental pollution in different sites from Buenos Aires and Montevideo. Environ. Monit. Assess. 178, 237-245. http://dx.doi.org/10.1007 s10661-010-1685-z.

Ferrat, M., Weiss, D.J., Strekopytov, S., Dong, S., Chen, H., Najorka, J., Sun, Y., Gupta, S. Tada, R., Sinha, R., 2011. Improved provenance tracing of Asian dust sources using rare earth elements and selected trace elements for palaeomonsoon studies on the eastern Tibetan Plateau. Geochim. Cosmochim. Acta 75, 6374-6399. http://dx.doi.org/10.1016/j.gca.2011.08.025.

Gandois, L., Probst, A., 2012. Localisation and mobility of trace metal in silver fir needles. Chemosphere 87, 204-210. http://dx.doi.org/10.1016/j.chemosphere. 2011.12.020.
Gandois, L., Tipping, E., Dumat, C., Probst, A., 2010. Canopy influence on trace metal atmospheric inputs on forest ecosystems: speciation in throughfall. Atmos. Environ. 44, 824-833.

Gandois, L., 2009. Dynamique et bilan des éléments traces métalliques (ETM) dans des écosystèmes forestiers français. Modélisation, spéciation et charges critiques. Thèse de l'Université de Toulouse. Université Toulouse III-Paul Sabatier.

Garty, J., 2001. Biomonitoring atmospheric heavy metals with lichens: theory and application. Crit. Rev. Plant Sci. 20, 309-371. http://dx.doi.org/10.1080/ 20013591099254

Godt, J., Schmidt, M., Mayer, R., 1986. Processes in the canopy of trees: internal and external turnover of elements. In: Georgii, H.-W. (Ed.), Atmospheric Pollutants in Forest Areas. Springer, Netherlands, pp. 263-274.

Govindaraju, K., 1994. Compilation of working values and description for 383 geostandards. Geostand. Newsl. 18, 1-158.

Gueguen, F., Stille, P., Geagea, M.L., Boutin, R., 2012. Atmospheric pollution in an urban environment by tree bark biomonitoring - part I: trace element analysis. Chemosphere 86, 1013-1019. http://dx.doi.org/10.1016/j.chemosphere. 2011.11.040.

Harmens, H., Ilyin, I., Mills, G., Aboal, J.R., Alber, R., Blum, O., Coşkun, M., De Temmerman, L., Fernández, JÁ., Figueira, R Frontasyeva, M Godzik, B. Goltsova, N., Jeran, Z., Korzekwa, S., Kubin, E., Kvietkus, K., Leblond, S., Liiv, S., Magnússon, S.H., Maňkovská, B., Nikodemus, O., Pesch, R., Poikolainen, J., Radnović, D., Rühling, ̊.., Santamaria, J.M., Schröder, W., Spiric, Z., Stafilov, T., Steinnes, E., Suchara, I., Tabors, G., Thöni, L., Turcsányi, G., Yurukova, L., Zechmeister, H.G., 2012. Country-specific correlations across Europe between modelled atmospheric cadmium and lead deposition and concentrations in mosses. Environ. Pollut. 166, 1-9. http://dx.doi.org/10.1016/j.envpol.2012.02.013.

Harmens, H., Norris, D.A., the Participants of the Moss Survey, 2008. Spatial and Temporal Trends in Heavy Metal Accumulation in Mosses in Europe (1990-2005). Programme Coordination Centre for the ICP Vegetation. Centre of Ecology and Hydrology, Bangor.

Harmens, H., Norris, D.A., Steinnes, E., Kubin, E., Piispanen, J., Alber, R., Aleksiayenak, Y., Blum, O., Coșkun, M., Dam, M., De Temmerman, L., Fernández, J.A., Frolova, M., Frontasyeva, M., González-Miqueo, L. Grodzińska, K., Jeran, Z., Korzekwa, S., Krmar, M., Kvietkus, K., Leblond, S., Liiv, S., Magnússon, S.H., Maňkovská, B., Pesch, R., Rühling, ̊̊., Santamaria, J.M., Schröder, W., Spiric, Z., Suchara, I., Thöni, L., Urumov, V., Yurukova, L., Zechmeister, H.G., 2010. Mosses as biomonitors of atmospheric heavy metal deposition: spatial patterns and temporal trends in Europe. Environ. Pollut. 158, 3144-3156. http://dx.doi.org/10.1016/j.envpol.2010.06.039.

Heinrichs, H., Mayer, R. 1977. Distribution and cycling of major and trace elements in two central European forest ecosystems. J. Environ. Qual. 6, 402-407.

Henderson, P., 1984. Rare Earth Element Geochemistry. Elsevier.

Hernandez, L., Probst, A., Probst, J.L., Ulrich, E., 2003. Heavy metal distribution in some French forest soils: evidence for atmospheric contamination. Sci. Total Environ. 312, 195-219. http://dx.doi.org/10.1016/S0048-9697(03)00223-7.

Hou, H., Takamatsu, T., Koshikawa, M.K., Hosomi, M., 2005. Trace metals in bulk precipitation and throughfall in a suburban area of Japan. Atmos. Environ. 39, 3583-3595. http://dx.doi.org/10.1016/j.atmosenv.2005.02.035.

Laveuf, C., Cornu, S., 2009. A review on the potentiality of rare earth elements to trace pedogenetic processes. Geoderma 154, 1-12. http://dx.doi.org/10.1016/ j.geoderma.2009.10.002.

Lindberg, S.E., Lovett, G.M., 1992. Deposition and forest canopy interactions of airborne sulfur: results from the integrated forest study. Atmos. Environ. Part A Gen. Top. 26, 1477-1492. http://dx.doi.org/10.1016/0960-1686(92)90133-6.

Mason, E., Hale, J., 1959. Studies on lichen growth rate and succession. Bull. Torrey Bot. Club 86, 126-129. http://dx.doi.org/10.2307/2482993.

Nieboer, E., Richardson, D.H.S., Tomassini, F.D., 1978. Mineral uptake and release by lichens: an overview. Bryologist 81, 226-246. http://dx.doi.org/10.2307/ 3242185.

Nriagu, J.O., 1990. Global metal pollution: poisoning the biosphere? Environ. Sci. Policy Sustain. Dev. 32, 7-33. http://dx.doi.org/10.1080/00139157. 1990.9929037.

Nriagu, J.O., Pacyna, J.M., 1988. Quantitative assessment of worldwide contamination of air, water and soils by trace metals. Nature 333, 134-139.

Petty, W.H., Lindberg, S.E., 1990. An intensive 1-month investigation of trace metal deposition and throughfall at a mountain spruce forest. Water. Air. Soil Pollut. 53, 213-226.

Probst, A., Viville, D., Ambroise, B., Dambrine, E., 1992. Hydrochemical budgets of a small forested granitic catchment exposed to acid deposition - the strengbach catchment case study (Vosges massif, France). Water. Air. Soil Pollut. 62, 337-347.

Prussia, C.M., Killingbeck, K.T., 1991. Concentrations of ten elements in two common foliose lichens: leachability, seasonality, and the influence of rock and tree bark substrates. Bryologist 94, 135-142. http://dx.doi.org/10.2307/3243688.

Rauch, J.N., Pacyna, J.M., 2009. Earth's global Ag, Al, Cr, Cu, Fe, Ni, Pb, and Zn cycles. Glob. Biogeochem. Cycles 23, 16 .

Schilling, J.S., Lehman, M.E., 2002. Bioindication of atmospheric heavy metal deposition in the Southeastern US using the moss Thuidium delicatulum. Atmos. Environ. 36, 1611-1618.

Shotyk, W., Weiss, D., Kramers, J.D., Frei, R., Cheburkin, A.K., Gloor, M., Reese, S., 2001. Geochemistry of the peat bog at Etang de la Gruère, Jura Mountains, Switzerland, and its record of atmospheric $\mathrm{Pb}$ and lithogenic trace metals (Sc, $\mathrm{Ti}, \mathrm{Y}, \mathrm{Zr}$, and REE) since 12,370 14C yr BP. Geochim. Cosmochim. Acta 65, 2337-2360. http://dx.doi.org/10.1016/S0016-7037(01)00586-5. 
Sloof, J.E., Wolterbeek, B.T., 1993. Substrate influence on epiphytic lichens. Environ. Monit. Assess. 25, 225-234. http://dx.doi.org/10.1007/BF00548023.

Spickova, J., Navratil, T., Rohovec, J., Mihaljevic, M., Kubinova, P., Minarik, L. Skrivan, P., 2010. The characteristics of rare earth elements in bulk precipitation, throughfall, foliage and lichens in the Lesni potok catchment and its vicinity, Czech Republic. Geochemistry 10, 383-390.

Steinnes, E., 1995. A critical evaluation of the use of naturally growing moss to monitor the deposition of atmospheric metals. Sci. Total Environ. 160-161, 243-249. http://dx.doi.org/10.1016/0048-9697(95)04360-D.

Steinnes, E., Allen, R.O., Petersen, H.M., Rambæk, J.P., Varskog, P., 1997. Evidence of large scale heavy-metal contamination of natural surface soils in Norway from long-range atmospheric transport. Sci. Total Environ. 205, 255-266. http:// dx.doi.org/10.1016/S0048-9697(97)00209-X.

Szczepaniak, K., Biziuk, M., 2003. Aspects of the biomonitoring studies using mosses and lichens as indicators of metal pollution. Environ. Res. 93, 221-230. http://dx.doi.org/10.1016/S0013-9351(03)00141-5.

Tricca, A., Stille, P., Steinmann, M., Kiefel, B., Samuel, J., Eikenberg, J., 1999. Rare earth elements and $\mathrm{Sr}$ and Nd isotopic compositions of dissolved and suspended loads from small river systems in the Vosges Mountains (France), the river
Rhine and groundwater. Chem. Geol. 160, 139-158. http://dx.doi.org/10.1016/ S0009-2541(99)00065-0.

Ulrich, B., Pankrath, J., 1983. Effects of Accumulation of Air Pollutants in Forest Ecosystems. D. Reidel Publishing Company, Germany.

Vidal, P., Bernard-Griffiths, J., Cocherie, A., Le Fort, P., Peucat, J.J., Sheppard, S.M.F. 1984. Geochemical comparison between Himalayan and Hercynian leucogranites. Phys. Earth Planet. Inter. 35, 179-190. http://dx.doi.org/10.1016/00319201(84)90041-4.

Weill, D.F., Drake, M.J., 1973. Europium anomaly in plagioclase feldspar: experimental results and semiquantitative model. Science 180, 1059-1060. http:/ dx.doi.org/10.1126/science.180.4090.1059.

Yang, X., Liu, Y., Li, C., Song, Y., Zhu, H., Jin, X., 2007. Rare earth elements of aeolian deposits in Northern China and their implications for determining the provenance of dust storms in Beijing. Geomorphology 87, 365-377. http://dx.doi.org/ 10.1016/j.geomorph.2006.10.004.

Zhang, J., Liu, C.-Q., 2004. Major and rare earth elements in rainwaters from Japan and East China Sea: natural and anthropogenic sources. Chem. Geol. 209, 315-326. http://dx.doi.org/10.1016/j.chemgeo.2004.06.014. 